\title{
ANALISIS KEPUASAN MASYARAKAT TERHADAP PELAYANAN DI BALAI PERBIBITAN DAN PENGEMBANGAN INSEMINASI BUATAN TERNAK SAPI PERAH BUNIKASIH
}

\author{
Oleh : \\ Rosda Malia**) \\ Santi Risnawati*)
}

\begin{abstract}
Abstrak
Penelitian ini bertujuan untuk mengetahui kinerja penyelenggaraan pelayanan yang telah dilaksanakan Di Balai Perbibitan Dan Pengembangan Inseminasi Buatan Ternak Sapi Perah Bunikasih, hasil penelitian menunjukan karakteristik konsumen BPPIB TSP Bunikasih yakni : mayoritas laki laki, berusia produktif, berpendidikan SLTA, mereka adalah pelajar SLTA yang datang ke Balai untuk magang atau praktek kerja lapangan di bidang peternakan sapi perah atau edukasi farm. Nilai rata-rata pelayanan terhadap Survei Kepuasan Masyarakat (SKM) di Balai Perbibitan dan Pengembangan Inseminasi Buatan Ternak Sapi Perah Bunikasih setelah dikonversi mendapatkan nilai 82,83 dan Mutu Pelayanan termasuk kategori "B" dengan hasil kinerja unit pelayanan adalah "Baik ".
\end{abstract}

Kata Kunci: Kepuasan Konsumen, Kualitas Pelayanan, BPPIB-TSP Bunikasih, Sapi Perah.

\begin{abstract}
This study aims to determine the performance of service delivery that has been carried out by the Bunikasih Dairy Cattle Breeding and Development Center, based on the 2019 Community Satisfaction Index. the results showed the characteristics of consumers BPPIB TSP Bunikasih namely: the majority of men, productive age, high school education, they are high school students who come to the Balai for internships or field work practices in the field of dairy farming or farm education. The average service value for the Community Satisfaction Survey at the Nursing Hall and Development of Bunikasih Dairy Cattle Insemination after being converted get a value of 82.83 and Service Quality is included in the category "B" with the results of service unit performance being "Good".

Keywords: Customer Satisfaction, Service Quality, Nursery And Development Center For Artificial Insemination In Dairy Cows Bunikasih, Dairy Cows.

*) Alumni Fakultas Sains Terapan UNSUR

**) Dosen Fakultas Sains Terapan UNSUR
\end{abstract}

\begin{tabular}{lccr} 
ANALISIS & KEPUASAN & \multicolumn{2}{c}{ MASYARAKAT } \\
TERHADAP & PELAYANAN & DI & BALAI \\
PERBIBITAN & DAN & PENGEMBANGAN \\
INSEMINASI & BUATAN & TERNAK & SAPI \\
PERAH BUNIKASIH & &
\end{tabular}




\section{PENDAHULUAN}

Salah satu kegiatan yang dilakukan oleh sebuah organisasi adalah memberikan pelayanan baik kepada unitunit kegiatan di dalam organisasi maupun kepada pihak di luar organisasi. Aktivitas pelayanan sangat berpengaruh terhadap pencapaian mutu dan kelancaran kegiatan organisasi serta berpengaruh terhadap pencapaian tujuan organisasi secara keseluruhan. Pelayanan yang diberikan tidak hanya sekadar memberikan bantuan terhadap kebutuhan pelanggan, tetapi juga memberikan pelayanan yang baik kepada pelanggan.

Organisasi publik dalam memberikan pelayanan yang baik dituntut untuk dapat bertindak cepat dan akurat. Hal tersebut merupakan sebuah kewajiban yang harus dilakukan. Bagi organisasi publik, pelayanan yang baik tercermin dari setiap efektivitas dan efisiensi kegiatan yang dilakukan dengan lancar. Semakin cepat dan akurat pelayanan yang diberikan maka kualitas pelayanan akan semakin baik.

Masyarakat membutuhkan pelayanan untuk memenuhi berbagai macam kebutuhan yang tidak dapat dipenuhi sendiri, bahkan secara ekstrim dapat dikatakan bahwa pelayanan tidak dapat dipisahkan dengan kehidupan manusia. Pelayanan publik yang sering dibutuhkan dalam bentuk barang publik maupun jasa publik. Contoh dari pelayanan dalam bentuk barang publik meliputi : jalan raya, air bersih, listrik dan sebagainya, sedangkan contoh pelayanan dalam bentuk jasa publik meliputi : pelayanan administrasi, kesehatan, pendidikan dan penyelenggaraan transportasi.

Pelayanan publik diberikan kepada masyarakat oleh pemerintah. Pemerintah mempunyai peranan penting untuk menyediakan layanan publik sesuai yang telah diamanatkan dalam UndangUndang. Undang-Undang Nomor 25 Tahun 2009 tentang pelayanan publik pasal 1 menyebutkan bahwa "Pelayanan publik adalah kegiatan atau rangkaian kegiatan dalam rangka pemenuhan kebutuhan pelayanan sesuai dengan peraturan perundang-undangan bagi setiap warga negara dan penduduk atas barang, jasa dan/atau pelayanan administratif yang disediakan oleh penyelenggara pelayanan publik".

Pemerintah sebagai penyedia layanan publik bertanggungjawab dan terus berupaya untuk memberikan pelayanan yang terbaik kepada masyarakat. Rendahnya mutu pelayanan publik yang diberikan oleh aparatur pemerintah menjadi citra buruk pemerintah di tengah masyarakat. Sebagian masyarakat yang pernah berurusan dengan birokrasi selalu mengeluh dan kecewa terhadap layanan yang berikan.

Pelayanan yang diberikan terlalu berbelit-belit dengan berbagai alasan yang kurang dapat diterima oleh masyarakat, sehingga pelayanan yang diberikan cenderung tidak efektif dan efisien. Keadaan yang demikian membuat masyarakat sebagai pengguna layanan publik tidak terpuaskan. Semua itu berakibat masyarakat enggan mengurus segala sesuatu yang berhubungan dengan birokrasi pemerintah secara langsung.

Salah satu kantor pemerintahan yang aktivitasnya memberikan pelayanan publik kepada masyarakat adalah Balai Perbibitan Dan Pengembangan Inseminasi Buatan Ternak Sapi Perah Bunikasih. Bentuk layanan yang diberikan berhubungan dengan Pelayanan Data dan Informasi, Pelayanan Penyediaan Narasumber, Pelayanan Layanan Pengaduan Layanan Publik, Pelayanan Magang dan Praktek Kerja Lapangan, Pelayanan Penjualan Bibit Ternak, Pelayanan Penjualan Susu Segar, Pelayanan Bantuan Bibit HPT, Pelayanan Kunjungan, Pelayanan Penelitian dan Pelayanan Bimbingan Kelompok/Bimtek.

Berdasarkan pengamatan awal yang telah dilakukan di Balai Perbibitan Dan Pengembangan Inseminasi Buatan Ternak Sapi Perah Bunikasih, terdapat beberapa 
permasalahan yang dijumpai pada bagian pelayanan. Fasilitas pelayanan merupakan salah satu aspek yang mempengaruhi kualitas pelayanan yang diberikan. Oleh karena itu, pemenuhan fasilitas pelayanan bagi pelanggan atau masyarakat merupakan salah satu hal yang perlu diperhatikan. Fasilitas pelayanan di Balai Perbibitan Dan Pengembangan Inseminasi Buatan Ternak Sapi Perah Bunikasih dianggap masih kurang memadai, seperti tidak adanya kotak saran, tempat duduk pada ruang tunggu yang masih kurang, serta belum tersedia tempat parkir yang aman dan nyaman. Hal ini dapat mengganggu dan menghambat kelancaran kegiatan pelayanan. Faktor lain yang dapat menghambat kelancaran kegiatan pelayanan adalah keamanan di Balai Perbibitan Dan Pengembangan Inseminasi Buatan Ternak Sapi Perah Bunikasih dianggap masih kurang. $\mathrm{Hal}$ ini dapat dilihat dari belum adanya petugas parkir, sehingga keamanan kendaraan masyarakat tidak terjamin.

Tujuan utama dari pelayanan publik adalah kepuasan masyarakat. Kepuasan ini dapat terwujud apabila pelayanan yang diberikan sesuai dengan standar pelayanan yang ditetapkan atau lebih baik dari standar pelayanan tersebut. Permasalahan yang masih sering dikeluhkan oleh sebagian masyarakat adalah waktu pelayanan. Waktu pemrosesan layanan kepada masyarakat sekitar dua minggu dianggap masih terlalu lama bagi masyarakat, walaupun lamanya layanan tersebut telah sesuai dengan ketentuan tentang standar waktu pelayanan publik yang ditetapkan dalam undang-undang nomor 25 tahun 2009 tentang pelayanan publik.

Kegiatan pelayanan yang diberikan Balai Perbibitan Dan Pengembangan Inseminasi Buatan Ternak Sapi Perah Bunikasih akan dinilai dari tingkat kepuasan masyarakat. Penilaian yang diberikan masyarakat menentukan ukuran kinerja pelayanan publik. Kegiatan yang dapat dilakukan untuk mengetahui pelayanan publik adalah dengan mengukur tingkat kepuasan masyarakat. Salah satu metode yang digunakan untuk mengetahui kualitas pelayanan suatu organisasi publik adalah dengan menggunakan Survei Kepuasan Masyarakat (SKM). Ketentuan mengenai Survei Kepuasan Masyarakat (SKM) tertuang dalam Keputusan Menteri Pendayagunaan Aparatur Negara Nomor Peraturan Menteri Pendayagunaan Aparatur Negara Dan Reformasi Birokrrasi Republik Indonesia, Nomor 14 Tahun 2017 tentang Pedomam Penyusunan Survei Kepuasan Masyarakat (SKM) Unit Penyelenggara Pelayanan Publik.

Tujuan yang ingin dicapai dalam penelitian ini adalah sebagai berikut :

1. Mengetahui karakteristik konsumen di Balai Perbibitan Dan Pengembangan Inseminasi Buatan Ternak Sapi Perah Bunikasih.

2. Mengetahui kepuasan masyarakat terhadap pelayanan Balai Perbibitan Dan Pengembangan Inseminasi Buatan Ternak Sapi Perah Bunikasih

\section{METODE PENELITIAN}

Penelitian dilaksanakan dari Bulan Januari 2019 sampai dengan Bulan Maret 2019 dengan lokasi di Balai Perbibitan dan Pengembangan Inseminasi Buatan Ternak Sapi Perah Bunikasih, Kp. Padalengsar Desa Bunikasih Kecamatan Warungkondang Kabupaten Cianjur. Lokasi tersebut ditentukan dengan cara sengaja (purposive), dengan pertimbangan bahwa Balai Perbibitan Dan Pengembangan Inseminasi Buatan Ternak Sapi Perah Bunikasih melakukan salah satu pelayanan publik.

Populasi merupakan sekumpulan objek yang menjadi pusat penelitian, yang memiliki informasi yang ingin diketahui. Populasi dalam penelitian ini adalah seluruh masyarakat yang menjadi pelanggan di Balai Perbibitan dan Pengembangan Inseminasi Buatan Ternak Sapi Perah Bunikasih. Besarnya populasi dalam penelitian dan mempertimbangkan 
faktor-faktor yang menunjang keberhasilan pelaksanaan penelitian maka dalam penelitian ini dilakukan sampling.

Teknik sampling yang digunakan dalam penelitian ini adalah teknik nonprobability sampling dengan jenis accidental sampling, yaitu teknik penentuan sampel berdasarkan faktor spontanitas, artinya siapa saja yang secara tidak sengaja bertemu dengan peneliti dan sesuai dengan karakteristik atau ciri-cirinya yaitu masyarakat yang menjadi pelanggan Balai Perbibitan dan Pengembangan Inseminasi Buatan Ternak Sapi Perah Bunikasih, maka orang tersebut dapat digunakan sebagai sampel (responden) sebagai dasar pengumpulan data. Sampel penelitian ditargetkan berjumlah 50 responden sesuai dengan jumlah minimal responden dalam penyusunan Survei Kepuasan Masyarakat yang dipilih secara tidak sengaja.

Penelitian ini menggunakan sumber data yang diperoleh secara lisan dan tertulis. Teknik pengumpulan data yang digunakan dalam penelitian ini meliputi:

\section{Observasi}

Observasi yaitu teknik pengumpulan data dimana peneliti mencatat informasi sebagaimana mereka saksikan selema penelitian. Menurut Sugiyono (2010), Teknik ini dilakukan dengan mengamati dan mencatat secara langsung di lokasi penelitian atas gejalagejala yang ada kaitannya dengan objek yang diteliti, sehingga melalui proses ini penulis berusaha mendapatkan data yang dibutuhkan. Observasi dilakukan dengan tujuan untuk mengetahui secara langsung tentang keadaan Balai Perbibitan dan Pengembangan Inseminasi Buatan Ternak Sapi Perah Bunikasih, lingkungan Balai Perbibitan dan Pengembangan Inseminasi Buatan Ternak Sapi Perah Bunikasih, fasilitas serta kegiatan pelayanan di Balai Perbibitan dan Pengembangan Inseminasi Buatan Ternak Sapi Perah Bunikasih sehingga peneliti mendapatkan data yang akurat dan relevan dengan tujuan penelitian yang diharapkan.

\section{Dokumentasi}

Dokumentasi digunakan untuk memperoleh informasi tentang keadaan Balai Perbibitan dan Pengembangan Inseminasi Buatan Ternak Sapi Perah Bunikasih, seperti informasi mengenai visi misi, togas pokok, fungsi dan struktur organisasi Balai Perbibitan dan Pengembangan Inseminasi Buatan Ternak Sapi Perah Bunikasih serta informasi lainnya yang tercatat dan dalam bentuk lainnya yang berupa catatan, agenda, maupun landasan hukum. Dokumentasi digunakan untuk melengkapi data yang telah diperoleh melalui observasi dan kuesioner dengan cara meminta data kepada pihak-pihak yang terkait baik berupa arsip atau dokumen

\section{Pengisian Kuesioner atau angket}

Kuesioner atau angket merupakan teknik pengumpulan data yang dilakukan dengan cara memberi seperangkat pertanyaan atau pernyataan tertulis kepada responden untuk dijawabnya. Angket merupakan teknik pengumpulan data yang efisien apabila peneliti tahu pasti variabel yang ingin diukur dan tahu apa yang bisa diharapkan dari responden. Pada penelitian ini, kuesioner atau angket digunakan untuk mengambil data tentang tingkat kepuasan masyarakat sebagai pelanggan dari pelayanan Balai Perbibitan dan Pengembangan Inseminasi Buatan Ternak Sapi Perah Bunikasih, jenis kuesioner atau angket yang digunakan adalah angket tertutup. Teknik ini dipilih karena memudahkan responden dalam memberikan jawaban dan dapat mempermudah peneliti dalam mengambil data

\section{Instrumen penelitian}

Instrumen penelitian adalah alat atau fasilitas yang digunakan oleh peneliti dalam mengumpulkan data agar penelitiannya lebih sistematis sehingga lebih mudah diolah. Instrumen penelitian digunakan oleh peneliti pada saat 
pengumpulan data sesuai dengan teknik pengumpulan data yang sudah ditentukan. Instrumen penelitian yang digunakan dalam penelitian ini adalah sebagai berikut:

\section{a) Pedoman observasi}

Pedoman observasi berisi pedoman yang telah disiapkan sebelumnya untuk memperoleh data mengenai kondisi fisik Balai Perbibitan dan Pengembangan Inseminasi Buatan Ternak Sapi Perah Bunikasih dalam menunjang pelaksanaan pelayanan publik. Pedoman observasi digunakan sebagai acuan untuk melakukan pengamatan agar sesuai dengan tujuan penelitian.

Tabel 3. Kisi-kisi Intrumen Angket Penelitian.

\begin{tabular}{lll}
\hline \multicolumn{1}{c}{ Komponen } & & \multicolumn{1}{c}{ Indikator } \\
${$\cline { 1 - 2 }$} }$ & & 1. Persyaratan Pelayanan \\
Kepuasan & 2. Sistem, Mekanisme, dan Prosedur \\
Masyarakat & 3. Waktu Penyelesaian \\
& 4. Biaya/Tarif \\
& 5. Produk Spesipikasi jenis pelayanan \\
& 6. Kompetensensi pelaksana \\
& 7. Perilaku Pelaksana \\
& 8. Sarana dan prasarana \\
& 9. Penanganan pengaduan, Saran dan masukan \\
\hline
\end{tabular}

b) Angket

Angket atau kuesioner yang digunakan untuk mengetahui tingkat Survei Kepuasan Masyarakat di Balai Perbibitan dan Pengembangan Inseminasi Buatan Ternak Sapi Perah
Bunikasih. Angket yang digunakan adalah jenis angket tertutup yang sudah disediakan alternatif jawaban sehingga responden hanya memilik salah satu jawaban yang tersedia.

Tabel 4. Skor Kriteria Penilaian.

\begin{tabular}{clc}
\hline No & \multicolumn{1}{c}{ Kriteria Penilaian } & Skor \\
\hline 1 & Sangat Puas & 4 \\
2 & Puas & 3 \\
3 & Kurang Puas & 2 \\
4 & Tidak Puas & 1 \\
\hline
\end{tabular}

Dalam Penelitian ini digunakan dua sumber data yaitu data primer dan data sekunder.

1. Data Primer yaitu data yang dikumpulkan sendiri oleh perorangan/suatu organisasi secara langsung dari objek yang diteliti dan untuk kepentingan studi yang bersangkutan yang dapat berupa interview dan observasi (Sugiono, 2010).

2. Data sekunder yaitu data yang diperoleh/ dikumpulkan dan disatukan oleh studi-studi sebelumnya atau yang diterbitkan oleh berbagai instansi lain. Data sekunder juga dapat diperoleh dari sumber tidak langsung berupa data dokumentasi arsip-arsip resmi.
Penelitian ini menggunakan teknik analisis data Survei Kepuasan Masyarakat sesuai dengan Peraturan Menteri Pendayagunaan Aparatur Negara Dan Reformasi Birokrrasi Republik Indonesia, Nomor 14 Tahun 2017 tentang Pedomam Penyusunan Survei Kepuasan Masyarakat (SKM) Unit Penyelenggara Pelayanan Publik. Teknik analisis data dilakukan dengan menggunakan nilai Survei Kepuasan Masyarakat (IKM) yang dihitung dengan menggunakan nilai ratarata tertimbang masing-masing unsur pelayanan. Pengelolaan data penelitian ditempuh dengan cara sebagai berikut :

\section{Editing}

Setelah angket diisi oleh responden dan dikembalikan kepada penulis, segera 
penulis meneliti kelengkapan dalam pengisian angket. Apabila ada kelengkapan atau jawaban angket yang tidak dijawab, penulis menghubungi responden yang bersangkutan untuk disempurnakan jawabannya agar angket tersebut sah. Penulis memilih atau menyortir data atau angket sedemikian rupa sehingga hanya angket yang terisi dengan benar dan sah yang diolah atau digunakan.

\section{Tabulasi}

Setelah data terkumpul, data tersebut diberikan skor terhadap jawaban 9 unsur Survei Kepuasan Masyarakat. Penelitian ini menggunakan table biasa atau main tabel, yaitu tabel yang disusun berdasarkan sifat responden tertentu dan tujuan tertentu. Tabel ini sifatnya kolektif dan memuat beberapa jenis informasi.

\section{Analisis SKM dan Interpretasi}

Berdasarkan Peraturan Menteri Pendayagunaan Aparatur Negara Dan Reformasi Birokrrasi Republik Indonesia, Nomor 14 Tahun 2017 tentang Pedomam Penyusunan Survei Kepuasan Masyarakat (SKM) Unit Penyelenggara Pelayanan Publik, terdapat 9 unsur atau indikator yang dikaji dalam penghitungan IKM. Setiap unsur pelayanan mempunyai penimbang yang sama dengan rumus sebagai berikut :

Bobot nilai rata-rata tertimbang $=$ jumlah bobot $-1=0,11$ jumlah unsur $\frac{1}{9}$

Guna memperoleh nilai IKM digunakan rumus sebagai berikut: SKM $=\frac{\text { Total dari Nilai Persepsi Per Unsur }}{\text { Total unsur yang terisi }}$

Guna mempermudah interpretasi nilai IKM yang berkisar 25- 100, sesuai dengan ketentuan dalam Peraturan Menteri Pendayagunaan Aparatur Negara Dan Reformasi Birokrrasi Republik Indonesia, Nomor 14 Tahun 2017 tentang Pedomam Penyusunan Survei Kepuasan Masyarakat (SKM) Unit Penyelenggara Pelayanan Publik, maka hasil penilaian tersebut diatas dikonversikan dengan nilai dasar 25, dengan rumus sebagai berikut :

\begin{tabular}{|cc|}
\hline \multicolumn{3}{|c|}{ SKM Unit pelayanan $\times$ 25 } \\
\hline Hasil perhitungan tersebut
\end{tabular}
kemudian dikategorikan sesuai dengan nilai persepsi dan interval nilai IKM seperti pada tabel 5. Sebagai berikut :

Tabel 5. Nilai Mutu Persepsi, Interval IKM, Interval Konversi IKM.

\begin{tabular}{ccccc}
\hline $\begin{array}{c}\text { Nilai } \\
\text { Persepsi }\end{array}$ & $\begin{array}{c}\text { Nilai Interval } \\
\text { (NI) }\end{array}$ & $\begin{array}{c}\text { Nilai Interval Konversi } \\
\text { (NIK) }\end{array}$ & $\begin{array}{c}\text { Mutu } \\
\text { Pelayanan } \\
(\mathbf{x})\end{array}$ & $\begin{array}{c}\text { Kinerja Unit } \\
\text { Pelayanan } \\
\text { (y) }\end{array}$ \\
\hline 1 & $1,00-2,5996$ & $25,00-64,99$ & $\mathrm{D}$ & Tidak Baik \\
2 & $2,60-3,064$ & $65,00-76,60$ & $\mathrm{C}$ & Kurang Baik \\
3 & $3,0644-3,532$ & $76,61-88,30$ & $\mathrm{~B}$ & Baik \\
4 & $3,5324-4,00$ & $88,31-100,00$ & $\mathrm{~A}$ & Sangat Baik \\
\hline
\end{tabular}

Sumber : Peraturan Menteri Pendayagunaan Aparatur Negara Dan Reformasi Birokrrasi Republik Indonesia, Nomor 14 Tahun 2017.

Guna mendapatkan nilai rata-rata tertimbang per unsur pelayanan, jumlah nilai rata-rata per unsur pelayanan dikalikan dengan 0,071 sebagai nilai bobot rata-rata tertimbang. Sedangkan nilai indeks komposit (gabungan) untuk setiap unit pelayanan, merupakan jumlah nilai rata-rata dari setiap unsur pelayanan dikalikan dengan penimbang yang sama, yaitu 0,071. Hasil dari nilai indeks komposit (gabungan) tersebut merupakan nilai IKM dari Balai Perbibitan dan Pengembangan Inseminasi Buatan Ternak Sapi Perah Bunikasih Kabupaten Cianjur.

\section{Penarikan Kesimpulan}

Langkah terakhir dalam teknik analisis data adalah menarik kesimpulan dari hasil penelitian dan pembahasan. Data yang berupa angka dari hasil angket dijelaskan dalam bentuk kalimat, sehingga diperoleh deskripsi hasil penelitian. 


\section{HASIL DAN PEMBAHASAN}

\section{Gambaran Umum BPPIB TSP Bunikasih}

BPPIB TSP Bunikasih berada pada posisi geografis $107^{\circ} 03^{\prime} \mathrm{BT}$ dan $6^{\circ} 50^{\prime} \mathrm{LS}$ dengan ketinggian $\pm 900 \mathrm{~m}$ dari permukaan laut. Suhu $18 \sim 22^{\circ} \mathrm{C}$ dan kelembaban 85\%. Curah hujan 266 $\mathrm{mm} /$ Tahun (musim hujan) dan 51 $\mathrm{mm} /$ Tahun (musim kemarau). Saat ini lokasi BPPIB TSP Bunikasih masuk ke dalam dua wilayah administratif di Kabupaten Cianjur yaitu :

- Kampung Padalengsar Desa Bunikasih Kecamatan Warungkondang seluas $162.290 \mathrm{~m}^{2}$

- Desa Padaluyu Kecamatan Cugenang seluas $59.930 \mathrm{~m}^{2}$.

Lokasi BPPIB TSP Bunikasih dapat dicapai melalui dua jalan masuk yaitu dari Jl. Rancagoong Warungkondang $( \pm 13 \mathrm{~km})$ atau dari tikungan tapal kuda BPPIB - TSP Bunikasiha Jalan Raya Cugenang $( \pm 9$ $\mathrm{km})$. Jalan tersebut dibangun oleh Pemerintah Kabupaten Cianjur untuk menghubungkan arus kendaraan Jakarta Bogor $\sim$ Bandung yang melewati Sukabumi tanpa harus melewati jaringan jalan di pusat kota Cianjur yang kepadatannya sudah cukup tinggi.

Lahan BPPIB TSP Bunikasih seluas 24,04 ha berada di kaki Gunung Gede serta masuk ke dalam dua wilayah administratif yaitu Desa Bunikasih Kecamatan Warungkondang dan Desa Padaluyu Kecamatan Cugenang.

Ada pun pemanfaatan lahan sampai dengan awal Tahun 2012 adalah sebagai berikut :
- Bangunan (kantor, kandang, perumahan karyawan, dll) seluas 1,3 ha $(5,91 \%)$.

- Jalan lokasi 0,45 ha (2,05\%).

- Kebun rumput seluas 19,9 ha (90,45\%), hampir 50\% bertopografi bukit.

- Lahan exercise seluas 0,26 ha $(1,18 \%)$.

- Kebun bambu seluas 0,025 ha $(0,11 \%)$.

- Lain-lain seluas 0,065 ha $(0,30 \%)$.

Secara umum lahan yang baru dimanfaatkan secara efektif hanya seluas 4,1 ha $(18,45 \%)$ dan semi efektif seluas 10,2 ha $(46,36 \%)$. Sedangkan lahan dengan topografi berbukit seluas 5,6 ha $(25,45 \%)$ belum digunakan secara efektif

\section{Karakteristik Konsumen}

Penelitian dilaksanakan di Balai Perbibitan dan Pengembangan Inseminasi Buatan Ternak Sapi Perah Bunikasih, pada Bulan Januari 2019 sampai dengan Bulan Maret 2019. Konsumen penelitian ini adalah masyarakat yang menjadi pelanggan pelayanan Balai Perbibitan dan Pengembangan Inseminasi Buatan Ternak Sapi Perah Bunikasih. Karakteristik konsumen seperti dibawah ini :

\section{Karakteristik Konsumen Berdasarkan Jenis Kelamin}

Karakteristik konsumen berdasarkan jenis kelamin dapat memberikan informasi kelompok mana yang dominan sehingga peningkatan kualitas pelayanan dapat dirancang dan diarahkan sesuai jenis kelamin yang dominan

Tabel 10. Distribusi Masyarakat Pengguna Layanan Jenis Kelamin.

\begin{tabular}{lcc}
\hline \multicolumn{1}{c}{ Jenis Kelamin } & Jumlah & $\mathbf{\%}$ \\
Laki-Laki & 29 & 58 \\
Perempuan & 21 & 42 \\
\hline Jumlah & $\mathbf{5 0}$ & $\mathbf{1 0 0}$ \\
\hline
\end{tabular}

Sumber: Data primer (diolah), 2019.

Data yang diperoleh melalui kuesioner yang diisi oleh konsumen menunjukan bahwa responden laki-laki sebesar 29 orang dengan persentase $58 \%$,

\begin{tabular}{|c|c|c|}
\hline ANALISIS & KEPUASAN & RAKAT \\
\hline TERHADAP & PELAYANAN & BALAI \\
\hline PERBIBITAN & PENGEMBA & NGAN \\
\hline INSEMINASI & TERNAK & SAP \\
\hline
\end{tabular}


sedangkan responden perempuan sebesar 21 orang dengan persentase $42 \%$. Jadi dapat disimpulkan bahwa mayoritas konsumen jenis kelamin laki-laki yang menggunakan layanan balai untuk memperdalam ilmu pengetahuan dibidang peternakan dalam bentuk edukasi farm.

\section{Karakteristik Berdasarkan Usia \\ Distribusi}

konsumen berdasarkan usia dapat dilihat pada Tabel 11. di bawah ini :

Tabel 11. Distribusi Masyarakat Pengguna Layanan Menurut Usia

\begin{tabular}{cccc}
\hline Umur & Laki-Laki & PEREMPUAN & JUMLAH \\
\hline < 25 Tahun & 29 & 16 & 45 \\
25-35 Tahun & 0 & 4 & 4 \\
36-45 Tahun & 0 & 1 & 1 \\
$>$ 45 Tahun & 0 & 0 & 0 \\
\hline
\end{tabular}

Sumber: Data primer (diolah), 2019.

Berdasarkan tabel 11 di atas dapat diketahui bahwa frekuensi karakteristik konsumen berdasarkan usia tertinggi terdapat pada interval umur kurang dari/sama dengan 25 tahun sebanyak 45 orang dengan proporsi $90 \%$. Sedangkan frekuensi terendah terdapat pada interval umur dari/sama dengan 36-45 tahun sebanyak 1 orang dengan proporsi $2 \%$. Konsumen berada pada usia produktif

\section{Karakteristik
Berdasarkan Pekerjaan}

Dalam pengelompokan konsumen berdasarkan pekerjaan, konsumen Balai Perbibitan dan Pengembangan Inseminasi Buatan Ternak Sapi Perah Bunikasih sebanyak 45 orang merupakan pelajar/mahasiswa dan 5 orang merupakan pekerjaan lainnya, disajikan pada Tabel 12.

Tabel 12. Pengelompokan Konsumen Berdasarkan Pekerjaan.

\begin{tabular}{cc}
\hline Pekerjaan & Jumlah Konsumen \\
\hline Pns/Tni/Polri & 0 \\
Pegawai Swasta & 0 \\
Wiraswasta/Usahawan & 0 \\
Pelajar/ Mahasiswa & 45 \\
Lainnya & 5 \\
\hline
\end{tabular}
Sumber: Data primer (diolah), 2019.

Mereka datang ke Balai untuk memperdalam ilmu pengetahuan dibidang peternakan dalam bentuk edukasi farm.
4. Karakteristik Konsumen Berdasarkan Pendidikan

Distribusi karakteristik konsumen berdasarkan pendidikan dapat dilihat pada Tabel 13. di bawah ini :

Tabel 13. Distribusi Masyarakat Pengguna Layanan Menurut Pendidikan.

\begin{tabular}{cc}
\hline PENDIDIKAN & JUMLAH KONSUMEN \\
\hline SD Kebawah & 0 \\
SLTP & 0 \\
SLTA & 45 \\
D1 - D2 - D3 & 0 \\
S -1 & 5 \\
S -2 & 0 \\
S -3 & 0 \\
\hline
\end{tabular}

Sumber: Data primer (diolah), 2019.

\begin{tabular}{llr} 
ANALISIS & KEPUASAN & \multicolumn{2}{c}{ MASYARAKAT } \\
TERHADAP & PELAYANAN & DI \\
PALAI \\
PERBIBITAN & DAN & PENGEMBANGAN \\
INSEMINASI & BUATAN & TERNAK SAPI \\
PERAH BUNIKASIH &
\end{tabular}


Berdasarkan tabel 13 di atas dapat diketahui bahwa frekuensi karakteristik konsumen berdasarkan jenis pendidikan terendah terdapat pada jenis pendidikan S-1 sebanyak 5 orang dengan proporsi $10 \%$. Sedangkan frekuensi tertinggi terdapat pada jenis pendidikan SLTA sebanyak 45 orang dengan proporsi 90\%. Jadi dapat disimpulkan bahwa mayoritas konsumen berdasarkan pendidikan ini adalah SLTA. Hal ini menunjukkan bahwa konsumen yang berkunjung ke balai yang memanfaatkan jasa layanan berupa Magang dan Praktek Kerja Lapangan untuk mendapatkan pengetahuan di bidang peternakan sapi perah atau edukasi farm.

Karakteristik konsumen adalah gambaran setiap setiap konsumen yang memiliki keunikan masing - masing. Gambaran ini perlu dipahami, agar tepat dalam memberikan pelayanan.

Hasil penelitian menunjukan karakteristik konsumen BPPIB TSP Bunikasih yakni : mayoritas laki - laki, berusia produktif, berpendidikan SLTA, mereka adalah pelajar SLTA yang datang ke balai untuk magang/praktek kerja lapangan di bidang peternakan sapi perah/edukasi farm.

Dengan gambaran seperti diatas, hendaknya balai meningkatkan pelayanan magang dan praktek kerja lapangan. Menyederhanakan prosedur dan meningkatkan sarana dan prasarana.

\section{Analisis Kepuasan Konsumen}

Berdasarkan analisis terhadap 9 unsur pelayanan (U), diperoleh nilai Kepuasan Masyarakat (SKM) tentang pelayanan di Balai Perbibitan dan Pengembangan Inseminasi Buatan Ternak Sapi Perah Bunikasih. Nilai rata-rata SKM Balai Perbibitan dan Pengembangan Inseminasi Buatan Ternak Sapi Perah Bunikasih sebesar 82,83 dengan skor pelayanan sebesar 3,31, mutu layanan B dan kinerja unit pelayanan "Baik". Nilai SKM dari setiap unsur pelayanan dapat dilihat pada tabel 14 di bawah ini :

Tabel 14. Nilai SKM dari setiap unsur pelayanan.

\begin{tabular}{|c|c|c|c|c|c|c|}
\hline No & Unsur Pelayanan & $\begin{array}{l}\text { Nilai Unsur } \\
\text { Pelayanan }\end{array}$ & $\begin{array}{c}\text { Nilai } \\
\text { Indeks }\end{array}$ & $\begin{array}{c}\text { SKM } \\
\text { konversi }\end{array}$ & $\begin{array}{c}\text { Mutu } \\
\text { Pelayanan }\end{array}$ & $\begin{array}{c}\text { Kinerja } \\
\text { Unit } \\
\text { Pelayanan } \\
\end{array}$ \\
\hline U 1 & Persyaratan Pelayanan & 3,40 & 0,37 & 85,00 & $\mathrm{~B}$ & BAIK \\
\hline U 2 & $\begin{array}{l}\text { Sistem, Mekanisme, } \\
\text { dan Prosedur }\end{array}$ & 3,32 & 0,37 & 83,00 & B & BAIK \\
\hline U 3 & Waktu Penyelesaian & 3,34 & 0,37 & 83,50 & B & BAIK \\
\hline U 4 & Biaya/Tarif & 3,28 & 0,36 & 82,00 & B & BAIK \\
\hline U 5 & $\begin{array}{l}\text { Produk Spesipikasi } \\
\text { jenis pelayanan }\end{array}$ & 3,30 & 0,36 & 82,50 & B & BAIK \\
\hline U 6 & $\begin{array}{l}\text { Kompetensensi } \\
\text { pelaksana }\end{array}$ & 3,32 & 0,37 & 83,00 & B & BAIK \\
\hline U 7 & Perilaku Pelaksana & 3,38 & 0,37 & 84,50 & B & BAIK \\
\hline U 8 & sarana dan prasarana & 3,24 & 0,36 & 81,00 & B & BAIK \\
\hline U 9 & $\begin{array}{l}\text { Penanganan } \\
\text { pengaduan, Saran dan } \\
\text { masukan }\end{array}$ & 3,54 & 0,39 & 88,50 & A & $\begin{array}{l}\text { SANGAT } \\
\text { BAIK }\end{array}$ \\
\hline & RATA-RATA & 30,13 & 3,31 & 82,83 & B & BAIK \\
\hline
\end{tabular}

Sumber: Data primer (diolah), 2019.

Berikut ini hasil penelitian Survei Kepuasan Masyarakat (SKM) dari masing-masing unsur :

1. Persyaratan Pelayanan Balai Berdasarkan hasil analisis Balai
Perbibitan dan Pengembangan Inseminasi Buatan Ternak Sapi Perah Bunikasih memiliki mutu pelayanan pada tingkat "B" dan kinerja unit pelayanan pada tingkat "Baik". 
Indikator persyaratan pelayanan balai terdapat pada kuisioner nomor 1 . Konsumen menilai persyaratan teknis maupun administratif yang dilaksanakan oleh balai sesuai dengan pengurusan jenis pelayanan.

\section{Sistem, Mekanisme, dan Prosedur}

Berdasarkan hasil analisis sistem, mekanisme dan prosedur Balai Perbibitan dan Pengembangan Inseminasi Buatan Ternak Sapi Perah Bunikasih memiliki mutu pelayanan berada pada tingkat "B" dan kinerja unit pelayanan pada tingkat "Baik".

Indikator Sistem, Mekanisme, dan Prosedur Balai terdapat pada kuisioner nomor 2, konsumen menilai mudah persyaratan tata cara pelayanan yang dibakukan bagi pemberi dan penerima pelayanan, termasuk pengaduan kepada konsumen menilai mudah karena tinggal datang untuk mengajukan dan hari itu pula langsung dapat jawabannya.

\section{Waktu Penyelesaian}

Berdasarkan hasil analisis waktu penyelesaian di Balai Perbibitan dan Pengembangan Inseminasi Buatan Ternak Sapi Perah Bunikasih memiliki mutu pelayanan berada pada tingkat "B" dan kinerja unit pelayanan pada tingkat "Baik".

Indikator Waktu Penyelesaian Balai terdapat pada kuisioner butir nomor 3 . Konsumen menilai cepat jangka waktu yang diperlukan untuk menyelesaikan seluruh proses pelayanan. Setiap jenis pelayanan dilaksanakan dalam 1 hari.

\section{Biaya/Tarif}

Berdasarkan hasil analisis biaya/tarif di Balai Perbibitan dan Pengembangan Inseminasi Buatan Ternak Sapi Perah Bunikasih memiliki mutu pelayanan berada pada tingkat "B" dan kinerja unit pelayanan pada tingkat "Baik".

Indikator Biaya/Tarif Balai terdapat pada kuisioner nomor $4 . \quad$ sesuai, konsumen menilai biaya/tarif yang dikenakan oleh balai tidak ada. Sehingga konsumen menilai baik dan dapat miningkatkan minat masyarat dalam memperoleh pengetahuan dibidang peternakan.

\section{Produk Spesifikasi Jenis Pelayanan}

Berdasarkan hasil analisis spesifikasi teknis di Balai Perbibitan dan Pengembangan Inseminasi Buatan Ternak Sapi Perah Bunikasih memiliki mutu pelayanan berada pada tingkat "B" dan kinerja unit pelayanan pada tingkat "Baik".

Indikator Produk spesifikasi jenis pelayanan Balai terdapat pada kuisioner nomor 5. Konsumen menilai hasil pelayanan yang telah diberikan dan diterima sesuai dengan ketentuan yang telah ditetapkan.

\section{Kompetensi pelayanan}

Indikator Kompetensi pelayanan Balai terdapat pada kuisioner nomor 6 . Konsumen menilai petugas/pegawai yang dibalai mempunyai kemampuan dibidang pengetahuan, keterampilan dan pengalaman serta mempunyai keahlian masing-masing dalam rangka memberikan edukasi.

\section{Perilaku pelaksana}

Berdasarkan hasil analisis perilaku pelaksana di Balai Perbibitan dan Pengembangan Inseminasi Buatan Ternak Sapi Perah Bunikasih memiliki mutu pelayanan berada pada tingkat "B" dan kinerja unit pelayanan pada tingkat "Baik". Indikator Perilaku pelaksana Balai terdapat pada kuisioner soal nomor 7 . Konsumen menilai sikap atau perilaku petugas terhadap konsumen baik sehingga konsumen puas terhadap pelayanan yang diberikan oleh balai.

\section{Penanganan pengaduan, saran dan} masukan

Berdasarkan hasil analisis penanganan pengaduan, saran dan masukan di Balai Perbibitan dan Pengembangan Inseminasi Buatan Ternak Sapi Perah Bunikasih memiliki mutu pelayanan berada pada tingkat "A" dan 
kinerja unit pelayanan pada tingkat "Sangat Baik".

Indikator Penanganan pengaduan, saran dan masukan Balai terdapat pada kuisioner nomor 8. Konsumen menilai pelayanan penanganan pengaduan, saran dan masukan sesuai dengan standar yang berlaku.

\section{Sarana dan prasarana}

Berdasarkan hasil analisis sarana dan prasarana di Balai Perbibitan dan Pengembangan Inseminasi Buatan Ternak Sapi Perah Bunikasih memiliki Sarana dan Prasarana pada tingkat "B" dan kinerja unit pelayanan pada tingkat "Baik".

Indikator Sarana dan prasarana Balai terdapat pada kuisioner nomor 9. Konsumen menilai sarana dan prasarana yang ada dibalai dikelola dengan baik, sehingga memberikan rasa aman dan nyaman pada konsumen.

Analisis kepuasan konsumen adalah perasaan senang atau kecewa seseorang yang muncul setelah membandingkan antara kinerja (hasil) produk yang dipikirkan terhadap kinerja (atau hasil) yang diharapkan. Hasil penelitian menujukan kepuasan konsumen BPPIB-TSP Bunikasih yakni : survei Kepuasan Masyarakat (SKM) dari masing-masing unsur yang dilaksanakan oleh balai rata-rata memiliki mutu pelayanan pada tingkat "B" dan kinerja unit pelayanan pada tingkat "Baik".

$$
\text { Dengan gambaran diatas, }
$$

hendaknya balai lebih menyederhanakan dari segi persyaratan pelayanan, Sistem, Mekanisme, Prosedur, Biaya/Tarif dan memperbaiki Produk Spesifikasi Jenis Pelayanan, Kompetensi pelayanan, Perilaku pelaksana serta meningkatkan Sarana dan prasarana yang ada di balai.

\section{KESIMPULAN}

Berdasarkan hasil penelitian dan pembahasan, maka hasil penelitian ini dapat diambil kesimpulan sebagai berikut :

1. Karakteristik konsumen di balai adalah: a) Karakteristik konsumen berdasarkan jenis kelamin menunjukan mayoritas konsumen berjenis kelamin laki-laki mereka datang ke balai untuk memperdalam ilmu pengetahuan dibidang peternakan.

b) Karakteristik konsumen berdasarkan usia tertinggi terdapat pada interval umur kurang dari/sama dengan 25 tahun sebanyak 45 orang dengan proporsi $90 \%$ dari 50 orang. Disimpulkan bahwa konsumen berada pada usia produktif.

c) Karakteristik konsumen berdasarkan pekerjaan, sebanyak 45 orang merupakan pelajar/mahasiswa dari 50 orang. Disimpulkan mereka datang ke Balai untuk memperdalam ilmu pengetahuan dibidang peternakan.

d) Karakteristik konsumen berdasarkan pendidikan bahwa mayoritas konsumen pendidikan SLTA.

2. Survei Kepuasan Masyarakat (SKM) di Balai Perbibitan dan Pengembangan Inseminasi Buatan Ternak Sapi Perah Bunikasih setelah dikonversi mendapatkan nilai 82,83 dan Mutu Pelayanan termasuk kategori "B" dengan hasil Kinerja unit pelayanan adalah "Baik ".

\section{DAFTAR PUSTAKA}

Adya Barata (2003), Dasar- Dasar Pelayanan Prima. Jakarta : Elex Media Kompetindo.

Baron dan Byrne dalam Prijatna (2012). Psikologi Sosial jilid 2. Jakarta: Erlangga.

Fandy Tjiptono dan Anastasia Diana. 2003. Total Quality Manajement. Edisi Revisi. Yogyakarta: Andi Offset.

Fandy Tjiptono (2004), Manajemen Jasa, Edisi Pertama, Yogyakarta. Andi Offset.

Fandy Tijptono dan Gregorius Chandra (2005). Service, Quality Satisfaction . Yogyakarta. Andi Offset.

Goetsch dan Davis Fandy Tjiptono dan Anastasia Diana, (2003), Pengantar 
Manajemen Mutu 2, Ed. Bahasa Indonesia, Jakarta: PT Prenhalindo. Gronroos Ratminto dan Atik Septi Winarsih (2005) Manajemen Pelayanan, disertai dengan pengembangan model konseptual, penerapan citizen's charter dan standar pelayanan minimal. Yogyakarta: Pustaka.

Harbani Pasolong. (2010). Kepemimpinan Birokrasi. Bandung: CV Alfabeta.

Kasmir. (2005). Etika Customer Service. Jakarta: PT Rajagrafindo Persada.

Keputusan Menteri Pendayagunaan Aparatur Negara (KEPMENPAN) Nomor 63 Tahun 2003 tentang Pedoman Umum Penyelenggaraan Pelayanan Publik.

Keputusan Menteri Pendayagunaan Aparatur Negara Nomor Peraturan Menteri Pendayagunaan Aparatur Negara Dan Reformasi Birokrrasi Republik Indonesia, Nomor 14 Tahun 2017 tentang Pedomam Penyusunan Survei Kepuasan Masyarakat (SKM) Unit Penyelenggara Pelayanan Publik.

Kotler dalam Fandy Tjiptono (2004), Manajemen Pemasaran, Edisi Millenium, Penerbit PT. Prenhallinda, Jakarta.

Kotler dan Keller (2007). Manajemen Pemasaran, Jilid I, Edisi. Kedua belas, PT. Indeks, Jakarta.

Lijan Poltak Sinambela, dkk. (2011). Reformasi Pelayanan Publik. Jakarta: Bumi Aksara.
Nasution M. N. (2001), Nasution, M. N. (2005). Manajemen Mutu Terpadu: Total Quality Management, Edisi Kedua, Ghalia Indonesia, Bogor.

Parasuraman, et al., Fandy Tjiptono (2004) A Conceptual Model of Service Quality and its Implication for future Research.Jounal of marketing.

Peraturan Gubernur Provinsi Jawa Barat Nomor : 81 Tahun 2017 tentangTugas Pokok, Fungsi, Rincian Tugas Unit dan tata Kerja Unit Pelaksana Teknis Daerah di Lingkungan Dinas Ketahanan Pangan Dan Peternakan Provinsi Jawa Barat.

Peraturan Menteri Pendayagunaan Aparatur Negara Dan Reformasi Birokrrasi Republik Indonesia, Nomor 14 Tahun 2017 tentang Pedomam Penyusunan Survei Kepuasan Masyarakat (SKM) Unit Penyelenggara Pelayanan Publik.

Rezki Teguh, dkk. 2015. Pengaruh Fasilitas Wisata dan Harga Terhadap Kepuasan Konsumen (Studi Pada Museum Satwa). Jurnal administrasi bisnis. Vol. 25 No. 1, hal 1-9.

Schnaars Harbani Pasolong ( 2010). Teori Administrasi Publik. Bandung: Alfabeta.

Sinambela Harbani Pasolong (2010). Teori Administrasi Publik. Bandung: Alfabeta. 